\title{
ICT and Challenges of Agricultural Extension Education
}

\author{
Deribe Kaske Kacharo (PhD) \\ Hawassa University, College of Agriculture, Faculty of Environment, Gender and Development Studies, \\ Ethiopia
}

\begin{abstract}
After the novel coronavirus outbreak, many countries closed universities. This situation urges to implement online delivery as an alternative method. This study aimed assessing the access to and use of ICT by students, the ICT competencies possessed by the students, and assesses the current level of students' readiness for online education methods. Sample of 106 undergraduate students were selected. Semi-structured survey questionnaire was used for data collection. The findings revealed that most of the students have very limited access to and use of different types of ICTs. Mobile phones are the most popular ICT tool used by students. Poor ICT using competencies is another problem observed. ICT experts in the field of online education need to plan smartphone-based technologies, and it is recommended to offer zero-rated access to specific educational websites, and offer free or discounted mobile Internet packages to all students who need it to switch to online classes.
\end{abstract}

Keywords: Online education; Coronavirus; Students; University; Mobile phones; ICT

DOI: $10.7176 /$ JIEA/10-4-04

Publication date:September $30^{\text {th }} 2020$

\section{Introduction}

Online education has become increasingly popular in the higher education of developed countries within the last two decades, and most higher education institutions in developed countries believe that this method of instruction will be critical for the future of higher education (Allen \& Seaman, 2014). The accessibility of the Internet and flexibility of online courses have made online education an integral part of higher education (Li \& Irby, 2008; Luyt, 2013; Lyons, 2004).

After the novel coronavirus (COVID-19) outbreak, many countries have decided to close schools, colleges, and universities. The Ethiopian government has also taken the coronavirus pandemic seriously in the last few weeks. The initial responses included the closure of private and government schools and universities as of March 24, 2020. The Association of African Universities (AAU) has called upon universities in Africa to move "urgently" to implement alternative methods of delivering teaching and learning using technology and other distance learning techniques in the wake of the closures of higher education institutions to limit the spread of COVID-19 (Dell and Sawahel, 2020). The pandemic is expected to have enormous economic consequences and it is also having a devastating impact on global education. According to the latest figures released by UNESCO, some 1.3 billion learners around the world were not able to attend school or university as of March 23, 2020. UNESCO's figures refer to learners enrolled at pre-primary, primary, lower-secondary, and upper-secondary levels of education as well as at the tertiary level (McCarthy, 2020).

As a means of migration strategy to the loss of learning due to the pandemic, in higher education, many universities and colleges are replacing traditional education systems with online delivery methods. In this regard, the outbreak of the virus and lockdowns could be used as the best opportunity for technology interventions for distance learning and virtual online classrooms. However, the online classroom is a new area for both teachers and students in African universities. According to Dell and Sawahel (2020), this transition of teaching method requires expertise in online education, staff, and student training as well as more human power in the area of IT personnel to support both the instructors and the students.

On the other hand, access to the Internet is highly limited in remote areas, and relatively poor infrastructure in developing nations, such as the supply of electricity, makes this worse (Gulati 2008). Low infrastructure is a fundamental problem for developing countries to deal with, and it might take a long time and huge funding to improve (Ihmeideh, 2009). In developing countries like Ethiopia, where there is poor Internet connectivity and frequent power interruptions, implementing online classrooms is a serious challenge. In addition to infrastructure and connectivity, teachers' and students' familiarity with online delivery tools and processes are also key factors in providing distance learning or delivering online classrooms. Therefore, programs that can quickly target those in most need are crucial.

The objectives of this study are to assess the access to and use of ICT resources by students, the ICT competencies possessed by the students, and assess the current level of students' readiness for the introduction of online education methods.

\section{Methods}

The target population was undergraduate agricultural extension students in Hawassa University (HU), College of 
Agriculture (COA), Faculty of Environment, Gender and Development Studies (FEGDS), and the Agricultural Extension (AgEx) program in Ethiopia. For this study, all students in the second, third, and fourth year total of 106 were taken as sample respondents. These students are those who are working in 16 zones of the southern regional state of Ethiopia as Agricultural Development agents (DA) in the Bureau of Agriculture and Governmentsponsored agricultural extension mid-carrier professionals. Data were collected using a semi-structured selfadministered survey questionnaire. The study fully follows the descriptive type of research.

\section{Results}

\subsection{Background information of the sample students}

Of the total students, $19(17.9 \%)$ were female and $87(82.1 \%)$ were male. All of the students were enrolled in the agricultural extension program in the faculty of FEGDS, but their field of specialization studied in the diploma program was different. Accordingly, more than half $(63.2 \%)$ of the students were from the plant science field of specialization (Table 1).

Table 4: Background information of students $(\mathrm{N}=106)$

\begin{tabular}{|c|c|c|c|}
\hline Variables & Response & Frequency & Percent \\
\hline \multirow{2}{*}{ Gender of students } & Female & 19 & 17.9 \\
\hline & Male & 87 & 82.1 \\
\hline \multirow{4}{*}{$\begin{array}{l}\text { Field of specialization in Diploma } \\
\text { program }\end{array}$} & Plant science & 67 & 63.2 \\
\hline & Animal Husbandry & 7 & 6.6 \\
\hline & NRM & 26 & 24.5 \\
\hline & Veterinary & 6 & 5.7 \\
\hline
\end{tabular}

NRM = Natural Resource Management

The mean age of students was 30.87, and the maximum and minimum ages of the students were 45 and 23 years, respectively. The average number of households (HHs) the students serving was 696.95 and the maximum number was $2735 \mathrm{HHs}$ (Table 2). All of the sampled students were government-employed and paid monthly salary. Table 5: Demographic information of students $(\mathrm{N}=106)$

\begin{tabular}{llllll}
\hline Variable & Unit & Mean & Std.D & Min. & Max. \\
\hline Age & Years & 30.87 & 5.286 & 23 & 45 \\
Number of households serving & Number & 696.95 & 431.654 & 137 & 2735 \\
Monthly salary & ETB & 4565.77 & 1256.530 & 2470 & 7364 \\
\hline
\end{tabular}

$\mathrm{ETB}=$ Ethiopian Birr (currently 33 Birr is equivalent to 1 USD)

\subsection{Students Access to and use of ICT}

Most of the students have no or very limited access to and use of different types of ICT resources except mobile phones such as desktop computers, laptop computers, and tablets. They are almost having no access to Wi-Fi or cable Internet services (Table 3).

Table 6: Access to and use of ICTs at the office $(\mathrm{N}=106)$

\begin{tabular}{llllll}
\hline Type of ICT resources & Response & Access to ICT & \multicolumn{2}{c}{ Use of ICT } \\
\cline { 3 - 6 } & & Frequency & $\%$ & Frequency & $\%$ \\
\hline \multirow{2}{*}{ Desktop computers } & Yes & 5 & 4.7 & 2 & 1.9 \\
& No & 101 & 95.3 & 104 & 98.1 \\
\hline \multirow{2}{*}{ Laptop computers } & Yes & 6 & 5.7 & 2 & 1.9 \\
\hline \multirow{2}{*}{ Tablet } & No & 100 & 94.3 & 104 & 98.1 \\
\hline \multirow{2}{*}{ Wi-Fi or Cable Internet } & Yes & 4 & 3.8 & 3 & 2.8 \\
& No & 102 & 96.2 & 103 & 97.2 \\
\hline
\end{tabular}

All of the students had their own mobile phones, and $86(81.1 \%)$ of the students had owned/used smartphones. Regarding money spent on mobile phone use, 91 (85.8\%) of the students spent less than 25 ETB per day, and only 15 (14.2\%) spent 26-50 Birr per day on mobile phone airtime for calling or data usage. However, 97.2\% of the students did not get any financial support for airtime, even calling about government activities (Table 4). All of the students who owned smartphones that is $86(81.1 \%)$ of the total students used the camera App and the Internet on their phones (Table 4). This indicates that there is an opportunity for implementing online education using smartphones. 
Table 7: Mobile phone ownership and usage $(\mathrm{N}=106)$

\begin{tabular}{llll}
\hline Variables & Response & Frequency & \% \\
\hline Type of mobile phone owned & Cell phone & 20 & 18.9 \\
& Smartphone & 86 & 81.1 \\
Money spent on mobile phone per day & $<25$ Birr & 91 & 85.8 \\
& $26-50$ Birr & 15 & 14.2 \\
Have you got any financial support for calling? & Yes & 3 & 2.8 \\
& No & 103 & 97.2 \\
Do you use Camera app of your mobile phone? & Yes & 86 & 81.1 \\
Do you use Internet on your mobile phone? & No & 20 & 18.9 \\
& Yes & 86 & 81.1 \\
\hline
\end{tabular}

Students those who have smartphones use the Internet for different purposes. About $86 \%$ of the students' primary purpose of using the Internet is to browse social media and $64 \%$ use to download different applications (Table 5).

Table 8: Purpose and frequency of using the Internet on mobile phones $(\mathrm{N}=86)$

\begin{tabular}{lrrrr}
\hline Variables & \multicolumn{2}{c}{ Most frequently } & \multicolumn{2}{c}{ Least frequently } \\
\cline { 2 - 4 } & Frequency & \multicolumn{1}{c}{$\%$} & Frequency & \% \\
\hline Primary purpose of using Internet is to brows social media & 74 & $\mathbf{8 6}$ & 12 & 14 \\
Primary purpose of using Internet is to receive and send emails & 32 & 37.2 & 54 & $\mathbf{6 2 . 8}$ \\
Primary purpose of using Internet is to download other Apps & 55 & $\mathbf{6 4}$ & 31 & 36 \\
\hline
\end{tabular}

Students encounter different problems when using mobile phones. This study revealed that out of the total students included in the study, $74.5 \%$ suffered from poor network connectivity, $64.2 \%$ complained about the high rate of pay for the services, $55.7 \%$ lacked electricity for charging their phone battery, and $51.9 \%$ had high cost of maintenance (Table 6). This result also complements that of Kacharo, Mvena, and Sife (2018) conducted a study on rural households' use of mobile phones in southern Ethiopia. Therefore, this shows that we have to work on the problem of infrastructure and improving connectivity.

Table 9: Major problems encountered when using mobile phones $(\mathrm{N}=106)$

\begin{tabular}{llll}
\hline Problems encountered & Response & Frequency & \% \\
\hline Poor network and reception & Yes & 79 & 74.5 \\
High rate pay for the service & Yes & 68 & 64.2 \\
Lack of electricity to recharge phone & Yes & 59 & 55.7 \\
High cost of maintenance & Yes & 55 & 51.9 \\
Application limitation & Yes & 46 & 43.4 \\
Language limitation & Yes & 31 & 29.2 \\
\hline
\end{tabular}

\subsection{Level of competencies possessed by students}

ICT competencies among students were measured on a five-point Likert's type of scale: 5 points for high level of competence (extensive experience in the skill area or very skilled), 4 points for moderately high level of competence (good experience in the skill area or skilled); 3=points for average level of competence (some experience in the skill area or average); 2 points for low level of competence ( little experience in the skill area or not very skilled) and 1 point for no level of competence (no experience in the skill area or not skilled at all). The study revealed that students either they have average skill or not very skilled or not skilled at all on most of the skill areas they were evaluated especially on using e-mail, preparing power point presentation, using e-library, computer Internet browsing, and data information management (Table 7). From this, we can conclude that most of the students currently not ready for implement online education systems. However, the study also revealed that students who use smartphones are able to handle online education if they have an orientation or provide a detailed step-by-step guide. 
Table 10: Level of competencies possessed by students $(\mathrm{N}=106)$

\begin{tabular}{|c|c|c|c|c|c|c|c|c|c|c|c|c|c|}
\hline \multirow[t]{4}{*}{ No } & \multirow{4}{*}{$\begin{array}{l}\text { Competency } \\
\text { areas } \quad \text { (Skill } \\
\text { areas) }\end{array}$} & \multirow{3}{*}{\multicolumn{2}{|c|}{$\begin{array}{c}\text { Very skilled } \\
\text { (5) }\end{array}$}} & \multirow{2}{*}{\multicolumn{2}{|c|}{ Skilled }} & \multirow{2}{*}{\multicolumn{2}{|c|}{ Average }} & \multirow{2}{*}{\multicolumn{2}{|c|}{$\begin{array}{l}\text { Not very } \\
\text { skilled }\end{array}$}} & \multirow{2}{*}{\multicolumn{2}{|c|}{$\begin{array}{c}\text { Not skilled } \\
\text { at all }\end{array}$}} & \multirow[t]{3}{*}{ Score } & \multirow[t]{4}{*}{ Rank } \\
\hline & & & & & & & & & & & & & \\
\hline & & & & & & & & & & & & & \\
\hline & & $\mathrm{n}$ & $\%$ & $\mathrm{~N}$ & $\%$ & $\mathrm{n}$ & $\%$ & $\mathrm{n}$ & $\%$ & $\mathrm{n}$ & $\%$ & & \\
\hline 1 & Word processing & 3 & 2.8 & 9 & 8.5 & 36 & 34.0 & 35 & 33.0 & 23 & 21.7 & 252 & 5 \\
\hline 2 & Data search & 4 & 3.8 & 18 & 17.0 & 32 & 30.2 & 27 & 25.5 & 25 & 23.6 & 267 & 4 \\
\hline 3 & Data analysis & 2 & 1.9 & 8 & 7.5 & 34 & 32.1 & 31 & 29.2 & 31 & 29.2 & 237 & 6 \\
\hline 4 & $\begin{array}{l}\text { Data/information } \\
\text { management }\end{array}$ & 1 & .9 & 8 & 7.5 & 25 & 23.6 & 35 & 33.0 & 37 & 34.9 & 219 & 7 \\
\hline 5 & $\begin{array}{l}\text { PowerPoint } \\
\text { presentation }\end{array}$ & 0 & 0 & 6 & 5.7 & 17 & 16.0 & 31 & 29.2 & 52 & 49.1 & 189 & 10 \\
\hline 6 & Using e-mail & 1 & .9 & 2 & 1.9 & 14 & 13.2 & 31 & 29.2 & 58 & 54.7 & 175 & 11 \\
\hline 7 & Using telegram & 14 & 13.2 & 11 & 10.4 & 28 & 26.4 & 23 & 21.7 & 30 & 28.3 & 274 & 3 \\
\hline 8 & $\begin{array}{l}\text { Mobile phone } \\
\text { browsing }\end{array}$ & 11 & 10.4 & 27 & 25.5 & 28 & 26.4 & 17 & 16.0 & 23 & 21.7 & 304 & 2 \\
\hline 9 & Computer & & & & & & & & & & & & \\
\hline & $\begin{array}{l}\text { Internet } \\
\text { Browsing }\end{array}$ & 2 & 1.9 & 8 & 7.5 & 17 & 16.0 & 26 & 24.5 & 53 & 50.0 & 198 & 8 \\
\hline 10 & $\begin{array}{lr}\text { Making } & \text { e- } \\
\text { payments } & \text { (e.g. } \\
\text { M-Birr, } & \text { CBE }\end{array}$ & & & & & & & & & & & & \\
\hline & $\begin{array}{l}\text { Birr, Amole, } \\
\text { mobile banking, } \\
\text { Internet } \\
\text { Banking ) }\end{array}$ & 8 & 7.5 & 17 & 16.0 & 20 & 18.9 & 23 & 21.7 & 38 & 35.8 & 252 & 5 \\
\hline 11 & Using e-library & 2 & 1.9 & 10 & 9.4 & 14 & 13.2 & 22 & 20.8 & 58 & 54.7 & 194 & 9 \\
\hline 12 & $\begin{array}{l}\text { Taking \& } \\
\text { sending pictures } \\
\text { electronically }\end{array}$ & 16 & 15.1 & 23 & 21.7 & 28 & 26.4 & 20 & 18.9 & 19 & 17.9 & 315 & 1 \\
\hline
\end{tabular}

\section{Conclusions}

In spite of all the sampled students being government employed with monthly salaries and offices that they are assigned to work in, they have no or very limited access to and use of different types of ICT resources such as desktop computers, laptop computers, and tablets, except mobile phones. This might be the major challenge for higher education institutions to introduce and implement online education to mitigate the COVID-19 pandemic impact on the higher education system. In addition to poor infrastructure and connectivity, poor ICT competencies among students is another challenge, where higher education institutions are expected to do more in addressing the treatment of COVID-19.

\section{Recommendations}

Most of the students have no or very limited access to and use of ICT resources like desktop computers, laptop computers, and tablets. However, except those who used cell phones, all smartphone users were able to get access the Internet using Ethio Gebeta mobile Internet packages from ethio-telecom. Therefore, ICT experts in the field of online education in higher education institutions in general, and particularly in universities, need to plan smartphone-based technologies that help online teaching.

Students are almost having no access to Wi-Fi or cable Internet services, and those who have smartphones get access of Internet buying Internet mobile packages with a high rate of pay for the services. Therefore, if we plan to use smartphones as a tool for online teaching, it is recommended to offer zero-rated access to specific educational websites, and offer free or discounted mobile Internet packages to all students who need it to switch to online classes. On the issue of student access to the Internet, universities must collaborate with telecommunications companies (Ethio-telecom) to facilitate the provision of affordable or free access to the Internet for as long as the students are accessing education-related websites and information.

Acknowledgements: I would like to express my gratitude to the students for their response and collaboration in the study.

Funding: This research did not receive any specific grant from funding agencies in the public, commercial, or notfor-profit sectors.

\section{Compliance with Ethical Standards}

Ethical Approval: All procedures performed in studies involving human participants were in accordance with the ethical standards of the Hawassa University School of Graduate Studies. 
Informed Consent: The research involved human participants, who were informed about the purpose of the research and that their participation was voluntary.

\section{References}

Allen, I. E., \& Seaman, J. (2014). Grade change: Tracking online education in the United States. Newburyport, MA: Sloan Consortium.

Deribe K. Kacharo, Zebedayo S. K. Mvena \& Alfred S. Sife (2018). Factors constraining rural households' use of mobile phones in accessing agricultural information in Southern Ethiopia, African Journal of Science, Technology, Innovation and Development, DOI:10.1080/20421338.2018.1541336

Fathi Mahmoud Ihmeideh (2009). Barriers to the use of technology in Jordanian pre-school settings, Technology, Pedagogy and Education, 18:3, 325-341, DOI: 10.1080/14759390903255619

Li, C., \& Irby, B. (2008). An Overview of online education: Attractiveness, benefits, challenges, concerns, and recommendations. College Student Journal, Part A, 42, 449-458.

Luyt, I. (2013). Bridging spaces: Cross-cultural perspectives on promoting positive online learning experiences. Journal of Educational Technology Systems, 42, 3-20.

Lyons, J. F. (2004). Teaching U.S. history online: Problems and prospects. The History Teacher, 37, 447-456.

Niall McCarthy (2020). COVID-19's staggering impact on global education. World Economic Forum. Retrieved from: https://www.weforum.org/agenda/2020/03/infographic- covid19-coronavirus-impact-global-educationhealth-schools/ site visited on 15/04/2020.

Sharon Dell and Wagdy Sawahel (2020). African universities urged to put classes online urgently. University World News. Weekly Newsletter, 20 March 2020. Retrieved from: https://www.universityworldnews.com/post.php?story=20200320093558384 site visited on 15/04/2020 